\title{
In vitro and in vivo cell tracking of chondrocytes of different origin by fluorescent PKH 26 and
} CMFDA

\author{
Weinand Christian ${ }^{1}$, Timothy S Johnson ${ }^{1}$, Thomas J Gill ${ }^{1}$ \\ ${ }^{1}$ Plastic Surgery Laboratory, Department of Plastic Surgery, Massachusetts General Hospital, WACC 453, 15 Parkman Street, Boston, MA, 02114, USA. Corre- \\ spondence should be addressed to Weinand C, MD (cweinand@partners.org), Tel.: 617 - 726-7797. \\ Received August 17, 2008; revised October 7, 2008; accepted October 7, 2008
}

\begin{abstract}
Tissue engineering techniques for cartilage repair to heal defects in joint surfaces is a clinical practice. Harvested autologous chondrocytes are expanded in culture and delivered in a suitable carrier medium back into the patient's joint defect. The defect is then subsequently filled by new cartilage. Whether the cells in the repair tissue originate from the engineered tissue of the host or are derived from the surrounding original cartilage remains a relevant question for the applied therapy. To answer this several methods exist to track cells, such as transfection of cells with LacZ carrying viruses, radio labeling with 111 IN or $51 \mathrm{Cr}$ or fluorescent labeling with FDA. However, these techniques have drawbacks such as they may influence cellular properties, are radioactive or quickly lose their tracking ability. New fluorescent probes are easier to handle and do not to interfere with cells.
\end{abstract}

PKH $26^{\circledR}$ is a relatively new cell-labeling agent, but few data exist on the application of this dye in chondrocytes in vitro and in vivo. 5-chloromethylfluorescein diacetate - CMFDA ("cell tracker green") is an established fluorescent probe for imaging the dynamic processes of cell proliferation in vitro and in vivo. Likewise, several studies exist on different cell types. However, little data are available for chondrocytes.

The first aim of this study was to evaluate qualitative differences in fluorescence pattern after labeling of articular, auricular and costal chondrocytes. Secondly, we evaluated the influence of labeling with CMFDA on cellular adhesion properties. The third aim was to compare the duration of cell labeling of chondrocytes of different origin with established CMFDA as standard and $\mathrm{PKH} 26^{\circledR}$ for 3 cell generations in vitro and 12 weeks in vivo. We show that chondrocytes from different origin can be labeled effectively with both PKH $26^{\circledR}$ and CMFDA. The PKH $26^{\circledR}$ labeled articular chondrocytes maintained fluorescence longer than CMFDA in vitro and in vivo. A higher percentage of articular chondrocytes remained stained at 63 days than auricular or costal chondrocytes.

Keywords: Cell tracking, cell generations, integration, fluorescence, chondrocytes of different origin, CMFDA, PKH 26, tissue engineering

\section{INTRODUCTION}

Applied tissue-engineering techniques are clinical reality in joint cartilage replacement and defect filling. The clinician harvests chondrocytes from the patient's joint surface of a non-weight bearing area. After expansion in culture the cells are re-implanted into the patient into an existing defect using a suitable carrier for the cells. The relevant question to justify the technique remains weather the defect surrounding chondrocytes are migrating into the lesion or if the new tissue originates from the implanted cells. To answer this durable and stable methods for cell staining are essential in long term follow up studies of transplanted cells in order to allow identification of the origin of the daughter cells. Several features are necessary The marker should be 1: detectable after a prolonged period of time, 2: be easy to handle, and 3: should not interfere with immunocytochemical staining to characterize the fate and differentiation of grafted cells in the host tissue, such as cartilage.

Different methods have been established to identify transplanted cells in host tissue such as bromodesoxyuridine - BrdU [7, 15] labeling of cells with $\left[{ }^{3} \mathrm{H}\right]$ thymidine $[2,14,15]$ or transfection with the LacZ gene or beta-galactosidase $[6,12,22]$ but each techniques has some method specific disadvantages, such as involved radioactivity or special security measures are needed when handling viruses. Newer labeling techniques use chemical integration of fluorescent dyes into cellular structures such as organs or membranes. PKH $26^{\circledR}$ has been described as a fluorescent dye integrating irreversibly into the cellular membrane of living cells, and its labeling efficiency is more than $90 \%$ for many different cell types $[9,18,20,21,23]$. However, little data is available 
on its effectiveness with chondrocytes. Chondrocytes have a slower metabolism and replication rate compared to liver cells or mesenchymal stem cells $[10,11]$. In addition, chondrocytes produce an extracellular matrix that encapsulates them and that is different from other matrices produced by e.g. osteocytes or keratinocytes. For these reasons cell-tracking dyes mentioned before might not be the best choice for chondrocytes. Several authors have recommended the use of CMFDA for labeling different cell types for long-term studies, which is easy to handle. It integrates into the cytoplasm of viable cells, independent from the cell cycle, and has been used in bone marrow derived stem cells [8] keratinocytes, myocytes and osteocytes [3], lymphocytes and U937 cells [4]. Despite these advantages, the duration of the labeling is not known and only few data are available on its use with chondrocytes. In a previous in vivo experiment, we used PKH $26^{\circledR}$ to label transplanted auricular and articular chondrocytes and transplanted them on a PLGA mesh into a created meniscus lesion in an in vivo model. Follow up was done after 12 weeks and staining remained visible of the transplanted cells [27]. However, no comparison of cell tracking dyes between chondrocytes of different origin has been done.

We evaluated the differences in PKH $26^{\circledR}$ and CMFDA durability of cell labeling in vitro for 9 weeks for 3 daughter cell generations and in vivo for 12 weeks in a long-term study. Also, differences in labeling of three different kinds of chondrocytes and the influence of the marker on cell replication rate were examined.

\section{MATERIAL AND METHODS}

\subsection{Chondrocyte Preparation}

Under sterile operating conditions articular, auricular and costal cartilage from 6 month-old Yorkshire swine were harvested. The cartilage was excised, rinsed in phosphate-buffered saline (PBS) with $2 \%$ antibiotics, and minced into $1-\mathrm{mm}^{3}$ pieces. The cartilage was digested at $37^{\circ} \mathrm{C}$ in a $5 \% \mathrm{CO}_{2}$ incubator for $12-18$ hours in Ham's F-12 media with Glutamax-1 (Gibco/BRL, Life Technologies, Grand Island, NY) containing $0.1 \%$ of collagenase Type 2 (Worthington Biochemical, Freehold, NJ) and $1 \%$ antibiotics. The solutions were then passed through a $100-\mu \mathrm{m}$ filter to remove undigested particles. The cell suspension of isolated chondrocytes was centrifuged at $1500 \mathrm{rpm}$ for 10 minutes, washed 3 times with PBS containing 1\% antibiotic/antimycotics (10.000units penicillin, $10 \mathrm{mg}$ streptomycin and $25 \mu \mathrm{g}$ amphotericin B, Sigma Chemical Co., St Louis, MO) and cell viability assessed using trypan blue exclusion. Only cells with a viability of $>90 \%$ were used in this study. Cell counting was done by a hemocytometer to the nearest $1 \times 10^{6}$ cells per $\mathrm{ml}$.

\subsection{Chondrocyte Labeling with PKH $26^{\circledR}$}

PKH $26^{\circledR}$ (Sigma Chemical Co., St Louis, MO): PKH $26^{\circledR}$ is a lipophilic dye with aliphatic tails that binds irreversi- bly into the lipid regions of the cell membrane. The amount of dye is then partitioned equally between daughter cells during mitosis and therefore decreases by half at each cell division.

All steps were performed at $25^{\circ} \mathrm{C}$, according to the manual of the producer. The cells were placed in a conical polypropylene tube (Falcon, Becton Dickinson Labware, Lincoln Park, NJ) at concentrations of $20 \times 10^{6}$ cells per ml and were washed once with serum free medium. The chondrocytes were centrifuged for 5 minutes, the supernatant aspirated and re-suspended in $1 \mathrm{ml}$ of Diluent $\mathrm{C}$. A stock solution of PKH $26^{\circledR}$ of $4 \times 10^{6} \mathrm{M}$ was prepared immediately before staining, added to the Diluent $\mathrm{C} /$ chondrocyte suspension, suspended and incubated at $25^{\circ} \mathrm{C}$ for 5 minutes. The tube was intermittently inverted to assure mixing. After adding $2 \mathrm{ml}$ of FBS (Sigma Chemical Co., St. Louis, MO) the cells were incubated for 1 minute and then the suspension was diluted with $4 \mathrm{ml}$ of complete medium, consistent of Ham's F12 medium with 10\% FBS, 1\% Glutamine (Mediatech Cellgro, VA), 50mg L-Ascorbic acid (Sigma Chemical Co., St. Louis, MO) and $1 \%$ antibiotics/antimycotics. The suspension was centrifuged for $10 \mathrm{~min}$ at $25^{\circ} \mathrm{C}$, the supernatant aspirated and the cells were transferred to a new tube for further 3 times of washing with $10 \mathrm{ml}$ of complete medium.

\subsection{Chondrocyte Labeling with CMFDA}

5 chloromethylfluorescein diacetate - CMFDA or "Cell tracker green" (Molecular Probes Inc., Eugene, OR): CMFDA passes through the cell membranes into the cell, where the chloromethyl group reacts with intracellular thiols, leading to a cell-impermeant fluorescent dye. CMFDA stained cells have been found to fluoresce brightly for at least 72 hours after incubation in fresh medium at $37^{\circ} \mathrm{C}$ and last through at least four cell divisions.

CMFD was warmed to room temperature and dissolved with anhydrous dimethylsulfoxide (DMSO) to a final concentration of $10 \mathrm{mM}$. This stock solution was diluted to a final working concentration of 5 and $10 \mu \mathrm{M}$ in serum free medium. We found the best labeling concentration to be $10 \mu \mathrm{M}$. All cells were spun in a centrifuge to obtain a pellet and the supernatant was aspirated and re-suspended in previously warmed probe containing medium. The cell medium suspension was then incubated for 45 minutes under growth conditions. Thereafter the cells were centrifuged once more, re-suspended in fresh pre-warmed medium and incubated for 30 minutes. The cells were then washed again.

\subsection{Seeding and Sample Preparation}

Successful labeling of the cells was confirmed by examination under a fluorescence microscope. Unlabeled controls did not fluoresce when evaluated under fluorescent microscope.

Cells were obtained for culturing and plating on $25 \mathrm{~cm}^{2}$ flasks (Falcon, Becton Dickinson Labware, Lincoln Park, NJ). We obtained auricular, articular and costal chondrocytes from native cartilage by collagenase $(0.1 \%)$ diges- 
tion. 400,000 cells were labeled, the rest served as unlabeled controls. The cell density in the flasks was 16,000 cells per $\mathrm{cm}^{2}$. From each chondrocyte source at least 3 flasks were prepared. Media was changed every other day for the plated and seeded cells. Photos were taken every 7 days from the flasks. All pictures were digitized to evaluate number of fluorescent cells for each cell type. This was performed with MetaMorph (Expansion Programs International, Inc. (Thunderstone), CA, U.S.A.), by 3 times counting 250 cells at each time point for each cell type, using random counting grids of the fluorescent microscope at predetermined schedule every 7 days until 63 days ( 9 weeks). Percentage was calculated and the mean value determined for each time point of observation (Table 3 ). The chondrocytes were passaged when confluent, until the third passage was reached at 16,000 cells $/ \mathrm{cm}^{2}$, using $0.25 \%$ Trypsin. The counted cells at the fixed counting schedule every 7 days were then compared to the cell number achieved at each passage.

For the in vivo part of the experiment chondrocytes of each source were labeled with PKH $26^{\circledR}$ and CMFDA. These cells and unlabeled controls were encapsulated in fibrin glue to a final concentration of 40 million cells per $\mathrm{ml}$. Immediately after the gelation of fibrin glue the constructs of $0.2 \mathrm{ml}$ volume were inserted into the subcutaneous pouch of a nude mouse. The constructs were harvested after 3 and 12 weeks time. The constructs were examined morphologically, snap frozen in liquid nitrogen and sent for histological examination. Frozen sections of four micrometers were taken and examined under a fluorescent microscope. The percentage of fluorescent cell number in the tissue was determined by the Metamorph (Expansion Programs International, Inc. (Thunderstone), CA, U.S.A.) program analysis.

\section{Results}

\subsection{Cultured Chondrocytes in Flasks}

Chondrocytes in culture were monitored until stain was no longer observed. PKH $26^{\circledR}$ labeled chondrocytes reflected brightly under the fluorescent microscope. La-

Table 1. PKH 26 ${ }^{\circledR}$ labeled chondrocytes - articular cells showed the longest lasting staining.

\begin{tabular}{|l|l|l|l|}
\hline Labeling method & PKH 26 $^{\circledR}$ & & \\
\hline Chondrocyte type & Articular & Auricular & Costal \\
\hline Day & $\begin{array}{l}\text { Cells fluo- } \\
\text { rescing }\end{array}$ & $\begin{array}{l}\text { Cells fluo- } \\
\text { rescing }\end{array}$ & $\begin{array}{l}\text { Cells fluo- } \\
\text { rescing }\end{array}$ \\
\hline 7 & $87.9 \%$ & $91.1 \%$ & $84.7 \%$ \\
\hline 14 & $73.4 \%$ & $79.2 \%$ & $76.7 \%$ \\
\hline 21 & $70.4 \%$ & $73.2 \%$ & $71.0 \%$ \\
\hline 28 & $63.2 \%$ & $50.3 \%$ & $52.5 \%$ \\
\hline 35 & $50.3 \%$ & $47.3 \%$ & $48.2 \%$ \\
\hline 42 & $44.1 \%$ & $42.0 \%$ & $43.3 \%$ \\
\hline 49 & $41.0 \%$ & $36.2 \%$ & $37.1 \%$ \\
\hline 56 & $33.1 \%$ & $26.6 \%$ & $24.3 \%$ \\
\hline 63 & $22.1 \%$ & $8.3 \%$ & $10.4 \%$ \\
\hline
\end{tabular}

beled cells with PKH $26^{\circledR}$ of all three sources were clearly separable from the background noise for the first 48 days. The chondrocytes were followed up until day 63, when fluorescence was no longer observed (Tables 1, 2).Weekly observation of the labeling of the chondrocytes showed less labeled chondrocytes after 14 days of culture. However, cells were still clearly distinguishable from background noise. After 28 days, fluorescence was less clear on fewer cells in each flask. Until day 63 the number of fluorescent chondrocytes decreased gradually. Only single cells were fluorescent, the articular chondrocytes revealed the clearest fluorescence and the highest number of labeled cells from day 49 (Tables 1, 2, Figure 1).

Chondrocytes labeled with CMFDA showed fluorescence only until day 14 . After that all three types of the chondrocytes did not reveal any further fluorescence capacity. CMFDA labeled auricular chondrocytes and controls were confluent after 12 days.

Both, PKH $26^{\circledR}$ labeled auricular chondrocytes and auricular controls were passaged first after 10 days of culturing. Each flask contained 1 million cells, i.e. 2.5 times the original cell number. More than $79 \%$ of the cells were fluorescent. At the second passage after 15 days in culture, more than $75 \%$ of the chondrocytes were labeled. The flasks contained 1 million cells, equaling 2.5 times the plated cell number. The third passage of PKH $26^{\circledR}$ labeled auricular chondrocytes was at 25 days, showing more than $50 \%$ of the cells labeled; controls were confluent after 29 days of culture. Labeled and unlabeled costal chondrocytes were confluent after 16 days. Flasks contained 1.5 million cells, 4 times the cell number of original plated cells. More than $71 \%$ of the labeled cells were fluorescent. At 28 days at the second passage, more than $52 \%$ costal chondrocytes were fluorescent. The flasks contained 2.5 times the original plated cell number. The third passage was performed after 42 days with $43 \%$ labeled chondrocytes. We counted 1 million stained and 1 million control chondrocytes in each flask equaling a 2.5 times passaged number of costal chondrocytes. PKH $26^{\circledR}$ labeled articular chondrocytes and controls were first passaged after 20 days. More than $70 \%$ of the chondrocytes were labeled. Flasks held 1 million chondrocytes each, which is a 2.5 times doubling rate. Articular chondrocytes were second time passaged at 35 days. 1 million chondrocytes per flask were counted, equaling 2.5 times the passaged cell number. The third passage at 42 days showed $44 \%$ of the cells fluorescent. Flasks contained 2.5 times the original plated cell number, i.e. 1 million

Table 2. CMFDA labeled cells - no fluorescence was detectable after 14 days in all three chondrocyte types.

\begin{tabular}{|l|l|l|l|}
\hline Labeling method & CMFDA & Auricular & Costal \\
\hline Chondrocyte type & Articular & $\begin{array}{l}\text { Cells fluo- } \\
\text { rescing }\end{array}$ & $\begin{array}{l}\text { Cells fluo- } \\
\text { rescing }\end{array}$ \\
\hline Day & $85.8 \%$ & $83.4 \%$ & $89.1 \%$ \\
\hline 7 & $43.2 \%$ & $38.2 \%$ & $37.2 \%$ \\
\hline 14 & Not detectable & $\begin{array}{l}\text { Not de- } \\
\text { tectable }\end{array}$ & $\begin{array}{l}\text { Not detect- } \\
\text { able }\end{array}$ \\
\hline 21 & \multicolumn{2}{|l}{} \\
\hline
\end{tabular}


Table 3. Number of cells and daughter cell generations in flasks at time points of passage. The CMFDA labeled articular and costal chondrocytes were not confluent when no labeling could be observed any longer. Controls represent unlabeled costal chondrocytes. The replication of the cells is not inhibited by the dye.

\begin{tabular}{|c|c|c|c|c|c|c|c|c|}
\hline $\begin{array}{l}\text { Labeling } \\
\text { method }\end{array}$ & PKH $26^{\circledR}$ & & & & & & & \\
\hline $\begin{array}{l}\text { Chondrocyte } \\
\text { type }\end{array}$ & Articular & & Auricular & & Costal & & Controls & \\
\hline Passage \# & Cell \# & $\begin{array}{l}\text { Genera- } \\
\text { tions }\end{array}$ & Cell \# & Generations & Cell \# & Generations & $\begin{array}{l}\text { Cell \# (aver- } \\
\text { age) }\end{array}$ & Generations \\
\hline 1 & $0.4 \times 10^{\wedge} 6$ & & $0.4 \times 10^{\wedge} 6$ & & $0.4 \times 10^{\wedge} 6$ & & $0.4 \times 10^{\wedge} 6$ & \\
\hline 2 & $1 \times 10^{\wedge} 6$ & 2 & $1 \times 10^{\wedge} 6$ & 2 & $1.5 \times 10^{\wedge} 6$ & 3 & $1.5 \times 10^{\wedge} 6$ & 3 \\
\hline 3 & $1 \times 10^{\wedge} 6$ & 2 & $1 \times 10^{\wedge} 6$ & 2 & $1 \times 10^{\wedge} 6$ & 2 & $1 \times 10^{\wedge} 6$ & 2 \\
\hline $\begin{array}{l}\text { Labeling } \\
\text { method }\end{array}$ & CMFDA & & & & & & & \\
\hline $\begin{array}{l}\text { Chondrocyte } \\
\text { type }\end{array}$ & Articular & & Auricular & & Costal & & Controls & \\
\hline Passage \# & Cell \# & $\begin{array}{l}\text { Genera- } \\
\text { tions }\end{array}$ & Cell \# & Generations & Cell \# & Generations & $\begin{array}{l}\text { Cell \# (aver- } \\
\text { age) }\end{array}$ & Generations \\
\hline 1 & $0.4 \times 10^{\wedge} 6$ & & $0.4 \times 10^{\wedge} 6$ & & $0.4 \times 10^{\wedge} 6$ & & $0.4 \times 10^{\wedge} 6$ & \\
\hline 2 & -- & -- & $1.5 \times 10^{\wedge} 6$ & 3 & -- & -- & $2 \times 10^{\wedge} 6$ & 4 \\
\hline 3 & -- & -- & -- & -- & -- & -- & -- & -- \\
\hline
\end{tabular}

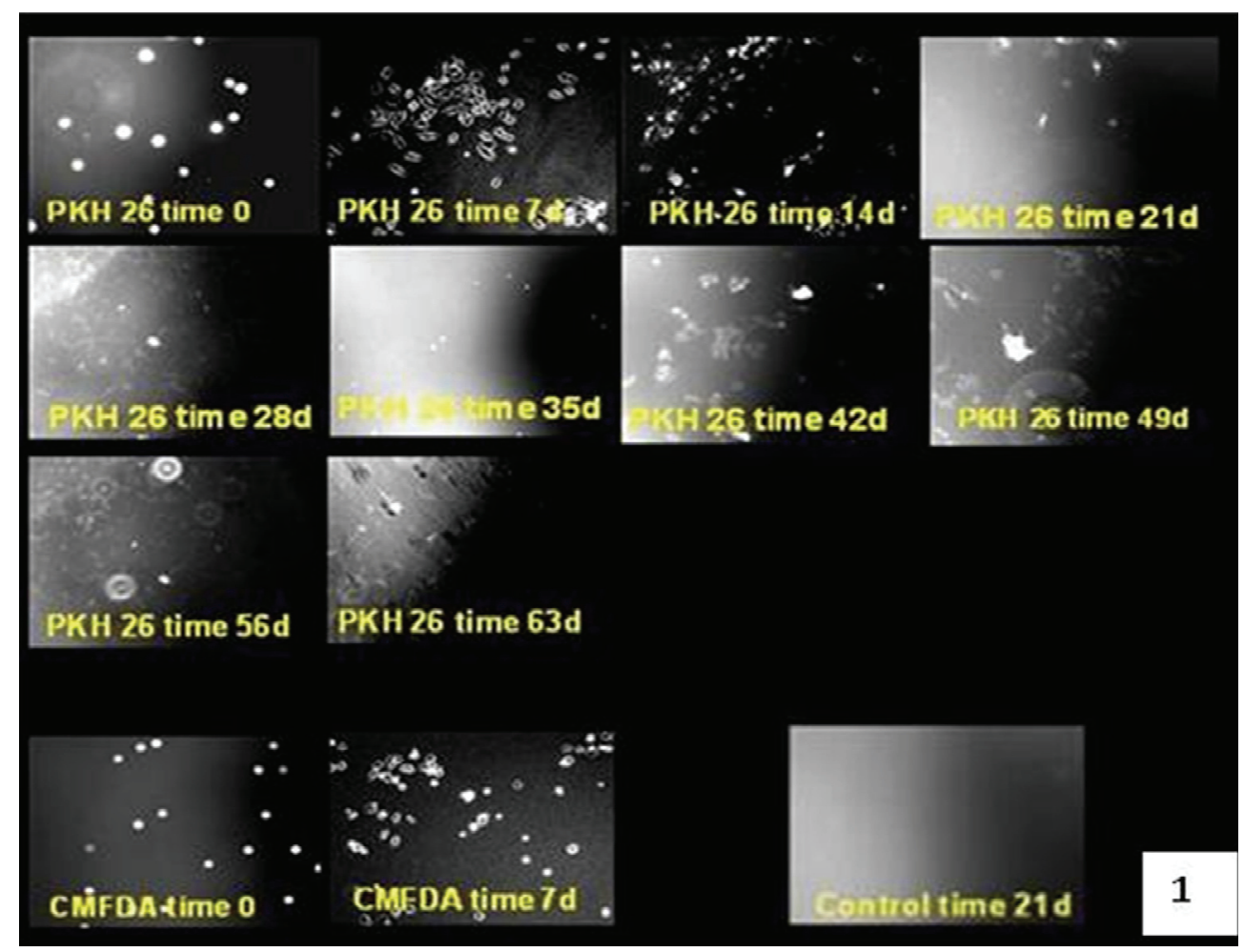

Figure 1. Seeded articular chondrocytes in flasks chondrocytes, labeled by PKH 26® and CMFDA show a loss of fluorescence over time. Time in days (time $x d$ ) Controls show no staining. Fluorescence microscope, 40x magnification.

chondrocytes (Table 3, Figure 1).

\subsection{Transplanted Chondrocytes in Vivo}

The constructs of PKH $26^{\circledR}$ and CMFDA stained chon drocytes in fibrin glue were harvested after 3 and 12 weeks. The samples were examined morphologically and histologically under a fluorescent microscope. The samples showed cartilage-like gross macroscopical appearance and had the consistency of cartilage. Under micro- scopic examination the fluorescence of PKH $26^{\circledR}$ labeled chondrocytes was bright and clearly distinguishable from the background (Figures 2, 3, 4, 5), even after 12 weeks in vivo after implantation. All three types of chondrocytes revealed the same pattern of fluorescence. Neo cartilage was formed and the daughter cells were tracked due to fluorescing.

The constructs containing CMFDA labeled chondrocytes of all three sources did not reveal fluorescence after 

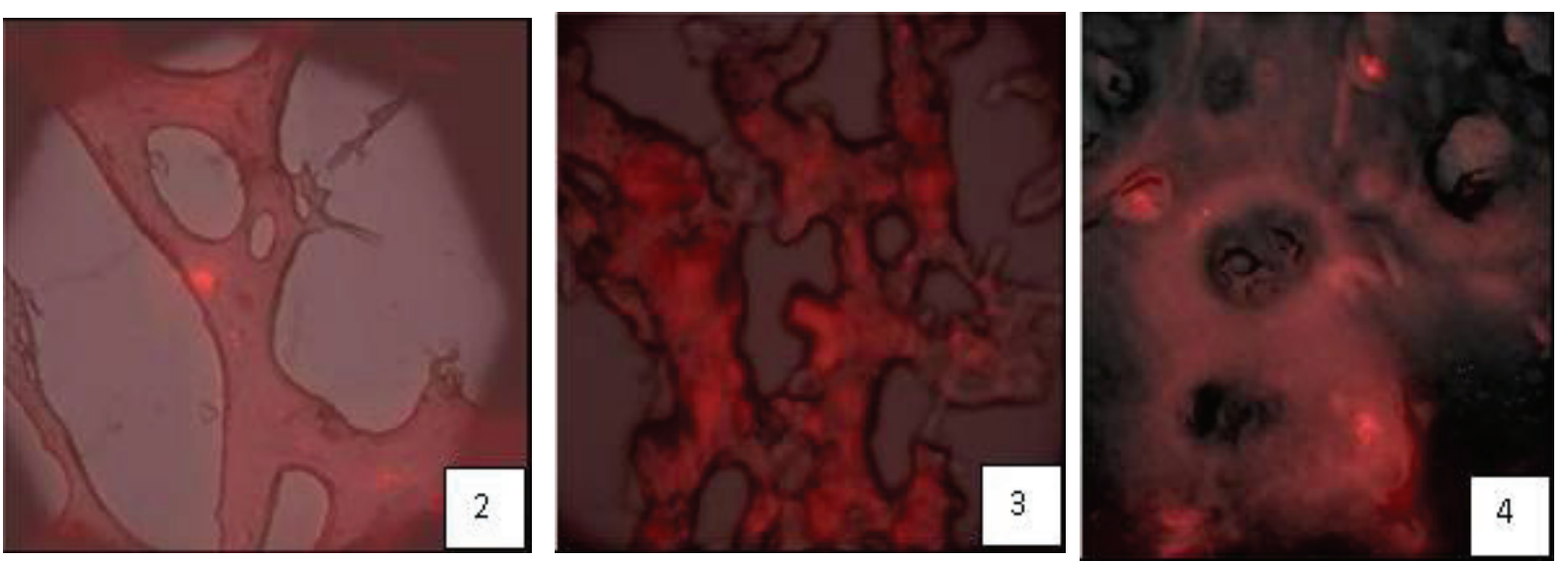

Figures 2, 3, 4. PKH $26 \circledast$ labeled articular, auricular and costal chondrocytes after 12 weeks in vivo. Fluorescence is clear distinguishable. Single cells are bright red fluorescent within the pale red fibrin glue hydrogel. Fluorescent microscope, 200x magnification.

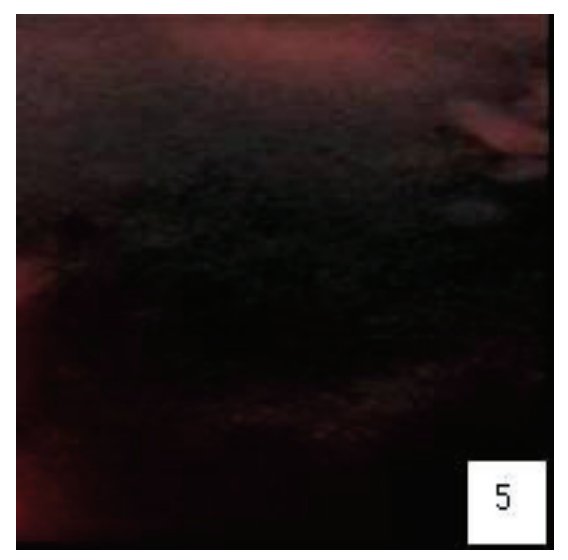

Figure 5. Controls with no fluorescent cells. Fluorescent microscope, 200x magnification.

3 and 12 weeks. None of the controls showed fluorescence (Figure 5).

\section{DISCUSSION}

In vitro and in vivo cell tracking is important to distinguish the origin of newly formed tissue. Data have been collected on different labeling techniques, such as BrdU - bromodesoxyuridine [7, 15], labeling of cells with $\left[{ }^{3} \mathrm{H}\right]$ - thymidine prior to transplantation $[2,14,15]$, or transfection with the LacZ gene or green fluorescent for the expression of beta - galactosidase $[6,12,22]$. These techniques have some method specific disadvantages. $\mathrm{BrdU}$ is a relatively expensive agent that depends on the synthesis phase of the cell cycle for integration and an additional secondary antibody is needed to detect labeled cells. In addition there is little information about the longevity of the labeling in cells. ${ }^{3} \mathrm{H}$ - thymidine is also cell cycle dependant and labeled cells have to be incubated for 2 months in order to detect the labeling [2, 14, 15]. The use of viral vectors to transport LacZ as a marker gene into cells requires specific timing for use and might cause unknown effects onto cells, such as immune reactions. Also, extra safety methods are required when using Adenovirus as a vector and the cell staining might last through only a few generations of daughter cells [6]. Other methods offered on the market are lipofection, which comes as a complete kit, but the transfection rate is low and the kits are rather expensive [16].

Thus, our goal was to identify labeling techniques that are stable with time, easy to use, and highly effective in cell labeling and cell staining for several generations culturing. They should also not be dependant on cell cycles for labeling chondrocytes for a long-term study.

In this long term in vitro and in vivo study we evaluated the durability and staining differences of two newer labeling methods in chondrocytes: PKH $26^{\circledR}$ and CMFDA. We labeled three different sources of cells and showed that there was no qualitative difference in labeling between articular, auricular and costal chondrocytes, using either PKH $26^{\circledR}$ or CMFDA. However, PKH $26^{\circledR}$ proved to be more durable in labeling than CMFDA over 63 days. This result was also found in our previous in vivo experiment, tracking transplanted chondrocytes in a meniscus [27]. All three types of chondrocytes were labeled under the same conditions at the same time. We did not observe any difference in the fluorescence of different chondrocytes at the beginning of the study, although a higher cell number of fluorescent articular chondrocytes was observed at day 63 in comparison to auricular or costal cells. The fluorescence of PKH $26^{\circledR}$ labeled chondrocytes was stable in vitro until day 63 , when only single cells showed fluorescence and the third passage was achieved. The longest lasting period for PKH $26^{\circledR}$ labeled cells in vivo was reported to be 4 months for neural cells post transplantation into the caudate putamen [9]. Other groups tracked labeled lymphocytes or peripheral blood mononuclear cells for shorter periods of time $[3,8,10,19]$, as well as neuronal precursors and neuronal cells $[9,23]$, endothelial cells [18], lymphocytes [20], L9292 cells [21] and hematopoetic stem cells

In contrast to PKH $26^{\circledR}$ CMFDA labeled chondrocytes revealed fluorescence only until day 14 , consistent with findings for myocytes, keratinocytes and osteocytes [3]. After that, no further fluorescence could be detected. 
Yang et al. labeled osteoprogenitor cells with CMFDA and fluorescence was visible until 4-6 weeks of in vitro culture [27]. This might indicate that lasting of fluorescence depends on the cell source labeled. The manufacturer states bright labeling will last for at least 72 hours (Molecular Probes, Product information 17-June-2002). We found similar results in our experiment.

Under high intensity illumination used for fluorescence microscopy irreversible destruction of the excited fluorophore often becomes the limiting factor for a long term follow up. This "photo bleaching" has been described by Song et al. [25] as photochemical reaction pathways; some involving reactions between adjacent dye molecules. Although some effective "antifade" reagents are available the majority of them are incompatible with living cells [11]. Photo bleaching might explain the quick fading of the CMFDA labeled chondrocytes. PKH $26{ }^{\circledR}$ were more stable when exposed to high intensity fluorescent light.

Tracking of different cells in vivo is described to after PKH $26^{\circledR}$ i.v. infusion $[1,17,19,24]$. Direct in vivo staining of lymphocytes with PKH $26^{\circledR}$ is possible by intramuscular injection [19. For our in vivo experiments we chose to label the chondrocytes in vitro and then implant the cells suspended in hydrogel, according to the technique described by Yang et al. [27] for osteoprogenitor cells and Lee-MacAry et al. for splenocyte effector cells [13]. Fluorescence was observed in the neo cartilage after 3 and 12 weeks in vivo. Fluorescence of the cells was clear and distinguishable at both time points, confirming the passage of the fluorescence dye by cell division to daughter cells. Thereby durable tracking of transplanted cells is provided and origin of the newly formed tissue could be defined to be from the transplanted chondrocytes. All three types of chondrocytes revealed stable fluorescence within the newly formed tissue. We did not observe any qualitative differences in fluorescence between the three cell types.

So far, only few data exist on the use of CMFDA or PKH $26^{\circledR}$ for labeling chondrocytes in vitro or in vivo. Further studies are necessary to evaluate the effects of this long lasting dye on chondrocytes on the cellular level. This study demonstrated that PKH $26^{\circledR}$ is the preferable marker for chondrocytes in a long-term study when tracking daughter cells. It can reliably label up to 63 days or 3 passages of cells, and serve as an indicator for the source of neo-cartilage in tissue-engineered constructs in vivo.

\section{ACKNOLEDGEMENT}

This study was generously funded by the Plastic Surgery Education Foundation

\section{REFERENCES}

[1] K.H. Albertine, M.H. Gee. (1996) In vivo labeling of neutrophils using a fluorescent cell linker. J Leukoc Biol 59, 631 - 638 .

[2] G. Andsberg, Z. Kokaia, A. Björklund, O. Lindvall, A. Martinez Serrano. (1998) Amelioration of ischemia - induced neural death in the rat striatum by NGF - secreting neural stem cells. Eur J Neurosci 10, 2026 - 2036

[3] P. Batard, M.N. Monier, N. Fortunel, K. Ducos, P. Sansilvestri Morel, T.H. Phan, A. Hatzfeld, J. Hatzfeld. (2000) TGF-beta 1 maintains the hematopoitic immaturity by a reversible negative control of cell cycle and induces CD 34 antigen up-modulation. J Cell Sci 113, 383- 390 .

[4] P.E.M. Butler, W.P. Lee, D.C. Sims, M.A. Randolph, C.A. Vacanti, MJ Yaremchuk. (1998) Cell transplantation from limb allografts. Plast Reconst Surg 102, $161-168$.

[5] M. Deutsch, M. Kaufman, H. Shapiro, N. Zurgil. (2000) Analysis of enzyme kinetics in individual living cells utilizing fluorescence intensity and polarization measurements Cytometry 39, $36-44$.

[6] C.H. Evans, S.C. Ghivizzani, T.A. Oligino, P.D. Robbins. (2001) Future of adenoviruses in the gene therapy of arthritis. Arthritis Res 3, 142-6.

[7] R.A. Fricker, M.K. Carpenter, C. Winkler, C. Greco, M. Gates., A Björklund. (1999) Site - specific migration and neural differentiation of human neural progenitor cells after transplantation into the adult rat brain. J Neurosci 19, $5990-6005$.

[8] A.L. Givan, J.L. Fisher, M. Waugh, M.S. Ernstoff, P.K. Wallace. (1999) A flow cytometric method to estimate the precursor frequencies of cells proliferating in response to specific antigens. $J$ Immunol Methods 230, $99-112$.

[9] S.J.P. Haas, P. Bauer, A. Rolfs, A. Wree. (2000) Immunocytochemical characterization of in vitro PKH 26 labeled and intracerebrally transplanted neonatal cells. Acta Histochem 102, 273 -280 .

[10] P.K. Horan, S.E. Slezak. (1989) Stable cell membrane labeling. Nature 340, $167-168$.

[11] I. Johnson. (1998) Fluorescent probes for living cells. Histochem J $30,123-140$

[12] C.C. Lai, P. Gouras, K Doi, F Lu, H Kjedlbye, SP Goff, R Pawliuk, P Leboulch, SH Tsang. (1999) Tracking RPE transplants labeled by retroviral gene transfer with green fluorescent protein. Invest Ophtalmol Vis Sci 40, $2141-2160$.

[13] A.E. Lee-MacAry, E.L. Ross, D. Davies, R.Laylor, J. Honeychurch, M.J.Glennie, D. Snary, R.W. Wilkinson. (2001) Development of a novel flow cytometric cell-mediated cytotoxicity assey using the fluorophores PKH 26 and TO-PRO-3 iodide. J Immunol Methods 252, $83-92$

[14] C. Lundberg, P.M. Field, Y.O. Ajayi, G. Raisman, A. Björklund. (1996) Conditionally immortalized neural progenitor cell lines integrate and differentiate after grafting to the adult rat striatum. A combined autoradiographic and electron microscopic study. Brain Res 737, 295-300.

[15] C. Lundberg, S.A. Martinez, E. Cattaneo, R.D.G. McKay, A Björklund. (1997) Survival, integration and differentiation of neural stem cell lines after transplantation to the adult rat striatum. Exp Neurol 145, $342-360$.

[16] H. Madry, S.B. Trippel. (2000) Efficient lipid-mediated gene transfer to articular chondrocytes. Gene Ther 7, 286-91.

[17] U. Maus, S. Herold, H. Muth, R. Maus, L. Ermert, M. Ermert, N. Weissmann, S. Rosseau, W. Seeger, F. Grimminger, J. Lohmeyer. (2001) Monocytes recruited into the alveolar air space of mice show a monocytic phenotype but upregulate CD 14. Am J Physiol Lung Cell Mol Physiol 280, L58 - L68.

[18] L.M. Messina, R.M. Podrazik, T.A. Whitehill, D. Ekhterae, T.E. Brothers, J.M. Wilson, W.E. Burkel, J.C. Stanley. (1992) Adhesion and incorporation of lacZ-transduced endothelial cells into the intact capillary wall in the rat. Proc Natl Acad Sci U S A. 89, 12018-12022.

[19] E.A. Mitchell, L.A. Bergmeister, C. Doyle, R. Brookes, L.A. Hussain, Y. Wang, T. Lehner. (1998) Homing of mononuclear cells from iliac lymph nodes to the genital and rectal mucosa in non-human primates. Eur J Immunol 28, 3066 - 3074.

[20] C.R. Parish. (1999) Fluorescent dyes for lymphocyte migration and proliferation studies. Immunol Cell Biol 77, 499-508.

[21] C. Rousselle, S. Paillasson, N.M. Robert, X. Ronot. (1999) Chromatin texture analysis in living cells. Histochem J 31, 63-70.

[22] O. Sabate, P. Horellou, E. Vigne, P. Colin, M Perricaudet, M.H. Buc - Caron, J. Mallet. (1995) Transplantation to the rat brain of human neural progenitors that were genetically modified using 
adenoviruses. Nat Genet 9, 256-260.

[23] V.L. Sheen, J.D. Macklis. (1995) Targeted neocortical cell death in adult mice guides migration and differentiation of transplanted embryonic neurons. J. Neurosci 15, 8378 - 8392.

[24] S.E. Slezak, P.K. Horan. (1989) Fluorescent in vivo tracking of hematopoietic cells. Part I. Technical considerations. Blood 74, $2172-2177$.

[25] L. Song, E.J. Hennink, I.T. Young, H.J. Tanke. (1995) Photobleaching kinetics of fluorescein in quantitative fluorescence microscopy. Biophys J 68, $2588-2600$.

[26] C. Weinand, J.W. Xu, G.M. Peretti, M.A. Randolph, L.J. Bonassar,
E. Savvidis., T.J. Gill. Conditions affecting chondrocyte seeding onto three-dimensional scaffolds. Submitted for Cells Tissues Organs.

[27] C. Weinand., G..M. Peretti., S.B. Adams, L.J. Bonassar., M.A.Randolph, Gill T.J. (2006) An allogeneic cell-based implant for meniscus lesions. Am J Sports Med 34, 1779 - 1789.

[28] X.B. Yang, H.I. Roach, N.M.P. Clarke, S.M. Howdle, R. Quirk, K.M. Shakesheff, R.O.C. Oreffo. (2001) Human osteoprogenitor growth and differentiation on synthetic biodegradable structures after surface modification. Bone 29, $523-531$. 